\title{
MENINGKATKAN HASIL BELAJAR IPS MELALUI PENERAPAN MODEL PEMBELAJARAN KOOPERATIF TIPE THINK-PHARE-SHARE (TPS) PADA SISWA KELAS VI SDN 1 DURUKA
}

\author{
Bakri Hasa ${ }^{1)}$, La Anse ${ }^{2)}$. \\ ${ }^{1)}$ SDN 1 Duruka, Muna, Indonesia \\ ${ }^{2)}$ Jurusan PGSD, Universitas Halu Oleo, Kendari, Indonesia \\ email: laanse56@gmail.com
}

\begin{abstract}
Abstrak: Penelitian ini bertujuan untuk meningkatkan hasil belajar IPS siswa kelas VI SD Negeri 1 Duruka materi pokok Kenampakan Alam dan Sosial NegaraNegara Tetangga melalui Model Pembelajaran Kooperatif Tipe Think-Phare-Share (TPS). Prosedur penelitian tindakan kelas yaitu; (a) perencanaan, (b) pelaksanaan tindakan, (c) observasi dan evaluasi, dan (d) refleksi. Data penelitian ini terdiri atas data kuantitatif dan data kualitatif. data kuantitatif diambil dari hasil tes belajar IPS siswa, sedangkan data kualitatif diambil dari lembar observasi dan tes hasil belajar siswa, selanjutnya data kualitatif dianalisis secara deskriptif kualitatif sedangkan data kuantitatif dianalisis secara deskriptif kuantitatif. Hasil penelitian menunjukkan bahwa penerapan Model Pembelajaran Kooperatif Tipe Think-PairShare (TPS) dapat meningkatkan hasil belajar IPS materi Kenampakan Alam dan Sosial Negara-negara Tetangga pada siswa Kelas VI SD Negeri 1 Duruka. Hal ini terlihat dari hasil tes siklus 1 menunjukkan bahwa 7 dari 20 siswa Kelas IV telah mencapai nilai $\geq 65$ dengan persentase ketuntasan $65 \%$ dan rata-rata kelas 63,25. Pada siklus II persentase ketuntasan $85 \%$ dengan rata-rata kelas 75,75. Hal tersebut menunjukkan bahwa kegiatan mengajar guru dengan menggunakan model pembelajaran kooperatif tipe Think-Pair-Share (TPS) telah dilaksanakan dengan baik dan mencapai indikator kinerja.
\end{abstract}

Kata Kunci: Model pembelajaran Kooperatif; Tipe TPS; Hasil Belajar.

\section{IMPROVING THE RESULTS OF IPS LEARNING THROUGH THE APPLICATION OF THINK-PHARE-SHARE (TPS) COOPERATIVE LEARNING MODEL FOR CLASS VI SDN 1 DURUKA}

\begin{abstract}
This study aims to improve the social studies learning outcomes of the VI grade students of SD Negeri 1 Duruka on the subject matter of the Nature and Social Appearances of neighboring countries through the Think-Phare-Share (TPS) Type of Cooperative Learning Model. Classroom action research procedures, namely; (a) planning, (b) implementing actions, (c) observation and evaluation, and $(d)$ reflection. This research data consists of quantitative data and qualitative data. Quantitative data were taken from the results of students' social studies learning tests, while qualitative data were taken from observation sheets and student learning outcomes tests, then qualitative data were analyzed descriptively qualitatively while quantitative data were analyzed descriptively quantitatively. The results showed that the application of the Think-Pair-Share (TPS) Type of Cooperative Learning Model can improve social studies learning outcomes in the Natural and Social Appearances of Neighboring Countries in Grade VI students of SD Negeri 1 Duruka. This can be seen from the results of the test cycle 1 shows that 7 out of 20 Class IV students have reached a value of $\geq 65$ with a percentage of $65 \%$ completeness and a class average of 63.25. In the second cycle the percentage of completeness was $85 \%$ with a class average of 75.75 . This shows that the teaching activities of teachers using the Think-Pair-Share (TPS) type of cooperative learning model have been implemented well and have achieved performance indicators.
\end{abstract}

Keywords: Cooperative learning model; TPS type; Learning outcomes 


\section{Pendahuluan}

Proses belajar mengajar merupakan dua hal yang berbeda tetapi membentuk satu kesatuan, ibarat sebuah mata uang yang bersisi dua. Belajar merupakan kegiatan yang dilakukan oleh siswa sedangkan mengajar adalah kegiatan yang dilakukan oleh guru. Kegiatan belajar mengajar yang dilakukan oleh guru sangat mempengaruhi kegiatan belajar siswa. Agar pelaksanaan pengajaran berjalan efisien dan efektif maka diperlukan perencanaan yang tersusun secara sistematis dengan proses belajar mengajar yang lebih bermakna dan mengaktifkan siswa serta dirancang dalam suatu skenario yang jelas (Ibrahim, 2003:30).

Belajar adalah suatu kegiatan yang berproses dan merupakan unsur yang sangat fundamental dalam setiap penyelenggaraan jenis dan jenjang pendidikan. Ini berati bahwa berhasil atau gagalnya pencapaian tujuan pendidikan itu sangat tergantung pada proses belajar yang dialami siswa (Syah, 2003 dalam Jihad, 2010:1). Selanjutnya Hamalik (2003:27) mengemukakan bahwa belajar adalah suatu usaha, perbuatan yang dilakukan secara sungguhsungguh, dengan sistematis, mendayagunakan semua potensi yang dimiliki, baik fisik, mental serta dana, panca indera, otak dan anggota tubuh lainnya, demikian pula aspek-aspek kejiwaan seperti inteligensi, bakat, motivasi, minat dan sebagainya.

Sudjana, 1996 dalam Jihad (2010:2) berpendapat bahwa belajar adalah suatu proses yang ditandai dengan adanya perubahan pada diri seseorang, seperti pengetahuan, pemahaman, sikap dan tingkah laku, keterampilan, kecakapan, kebiasaan serta perubahan aspek-aspek yang ada pada individu yang belajar. Sejalan dengan itu, menurut Sunaryo, 1989 dalam Komalasari (2010:2) belajar merupakan suatu kegiatan dimana seseorang membuat atau menghasilkan suatu perubahan tingkah laku yang ada pada dirinya dalam pengetahuan, sikap dan keterampilan. Lebih lanjut Slameto (2003:2) merumuskan belajar sebagai suatu proses usaha yang dilakukan seseorang untuk memperoleh perubahan tingkah laku yang baru secara keseluruhan sebagai hasil pengalamannya sendiri dalam interaksi dengan lingkungannya. Sedangkan menurut Fathurrohman (2007:6) belajar pada hakekatnya adalah perubahan-perubahan yang terjadi di dalam diri seseorang setelah melakukan aktifitas tertentu.

Mengajar merupakan suatu proses yang kompleks. Tidak hanya sekedar menyampaikan informasi dari guru kepada siswa. Banyak kegiatan maupun tindakan yang harus dilakukan, terutama bila diinginkan hasil belajar lebih baik pada seluruh siswa. Mengajar adalah suatu upaya yang disengaja dalam rangka memberi kemungkinan bagi siswa untuk terjadinya proses belajar sesuai dengan tujuan yang telah dirumuskan (Ali, 1992 dalam Fathurrohman 2007:7).

Mengajar atau "teaching" adalah membantu siswa memperoleh informasi, ide, keterampilan, nilai, cara berpikir, sarana untuk mengekspresikan dirinya dan cara-cara bagaimana belajar (Joyce dan Well, 1996 dalam Sugiyanto, 2010:3).

Slameto (2003:39) mengungkapkan bahwa mengajar adalah penyerahan kebudayaan kepada anak didik yang berupa pengalaman dan kecakapan atau usaha untuk mewariskan kebudayaan masyarakat kepada generasi berikutnya. Sementara itu menurut De Queliy mengajar adalah menanamkan pengetahuan pada seseorang dengan cara yang paling cepat dan tepat. Sedangkan menurut teori modern, teching is the guidance of learning. Mengajar adalah bimbingan kepada siswa dalam proses belajar (Slameto, 2003:30).

Hamalik (2003:31) mendefinisikan mengajar sebagai usaha mengorganisir lingkungan sehingga menciptakan kondisi belajar bagi siswa. Pendapat yang sama disampaikan oleh Howard, menyatakan bahwa mengajar adalah suatu aktifitas membimbing atau menolong seseorang untuk mendapatkan, mengubah atau mengembangkan keterampilan, sikap, cita-cita, pengetahuan dan penghargaan (Slameto, 2003:30). Selanjutnya menurut Jihad (2010:10) menafsirkan bahwa mengajar merupakan suatu usaha atau kegiatan yang dilakukan 
guru dalam mempersiapkan lingkungan pembelajaran yang meliputi lingkungan alam dan sosial yang mendudukung terjadinya proses belajar akibat interaksi antara siswa dengan lingkungan.

Berdasarkan pendapat di atas dapat disimpulkan bahwa belajar adalah suatu proses perubahan tingkah laku dalam pengetahuan, sikap dan keterampilan yang diperoleh dalam jangka waktu yang lama sedangkan mengajar merupakan suatu bentuk kegiatan pembimbingan oleh pendidik kepada peserta didik untuk dapat memperoleh pengetahuan atau pengalaman sebagai hasil proses belajar sesuai dengan tujuan pembelajaran yang diinginkan

Dari beberapa pendapat para ahli dapat disimpulkan bahwa seseorang dikatakan belajar, bila dapat diasumsikan didalam diri orang itu menjadi suatu proses kegiatan yang mengakibatkan suatu perubahan tingkah laku. Kegiatan atau usaha untuk mencapai perubahan tingkah laku merupakan proses belajar sedangkan perubahan tingkah laku yang terjadi pada individu disebut hasil belajar.

Penelitian yang dilakukan oleh Hartini, dkk (2016) Berdasarkan penelitian yang telah dilakukan maka dapat disimpulkan bahwa penerapan model pembelajaran Think-Pair-Share di MTs Negeri Pagedangan dapat meningkatkan kemampuan komunikasi matematis siswa lebih baik dibandingkan dengan pembelajaran konvensional. Hal ini dapat dilihat selama proses pembelajaran di dalam kelas. Pada pembelajaran dengan menggunakan model Thinkpairshare (TPS) siswa dituntut untuk berkomunikasi dengan temannya untuk mengungkapkan hasil pemikirannya.

Penelitian ini adalah penelitian tindakan kelas (PTK). Ciri khusus PTK adalah adanya tindakan nyata yang dilakukan sebagai bagian dari kegiatan penelitian dalam rangka memecahkan masalah. PTK merupakan penelitian yang dilakukan oleh guru di kelas dengan cara merencanakan, melaksanakan dan merefleksikan tindakan secara kolaboratif dan partisipasi dengan tujuan memperbaiki kinerjanya sebagai guru, sehingga hasil belajar sisiwa dapat meningkat. Dalam PTK ini dilaksanakan dua siklus dengan empat kali pertemuan, siklus I dua kali pertemuan dan siklus II dua kali pertemuan. Penelitian ini dilaksanakan di kelas VI SD Negeri 1 Duruka pada semester Ganjil Tahun Pelajaran 2016/2017. Subyek penelitian ini adalah siswa kelas VI SD Negeri 1 Duruka yang terdaftar pada Tahun Ajaran 2016/2017berjumlah 20 orang siswa yang aktif.

\section{Metode}

Penelitian ini adalah penelitian tindakan kelas (PTK). Ciri khusus PTK adalah adanya tindakan nyata yang dilakukan sebagai bagian dari kegiatan penelitian dalam rangka memecahkan masalah. PTK merupakan penelitian yang dilakukan oleh guru di kelas dengan cara merencanakan, melaksanakan dan merefleksikan tindakan secara kolaboratif dan partisipasi dengan tujuan memperbaiki kinerjanya sebagai guru, sehingga hasil belajar sisiwa dapat meningkat. Dalam PTK ini dilaksanakan dua siklus dengan empat kali pertemuan, siklus I dua kali pertemuan dan siklus II dua kali pertemuan. Penelitian ini dilaksanakan di kelas VI SD Negeri 1 Duruka pada semester Ganjil Tahun Pelajaran 2016/2017. Subyek penelitian ini adalah siswa kelas VI SD Negeri 1 Duruka yang terdaftar pada Tahun Ajaran 2016/2017 berjumlah 20 orang siswa yang aktif. Penelitian tindakan kelas ini terdiri dari 2 (dua) siklus. Tiap siklus terdiri dari dua kali pertemuan yang dilaksanakan berdasarkan indikator yang ingin dicapai pada setiap faktor yang akan diselidiki. Setiap siklus terdiri dari 4 tahapan yang harus dijalani, yaitu: Perencanaan, Pelaksanaan tindakan, Observasi, evaluasi dan refleksi.

Data yang diperoleh dalam penelitian ini dianalisis dengan menggunakan statistik deskriptif yang dimaksudkan untuk memberikan gambaran distribusi hasil belajar siswa yang 
diajar dengan menggunakan model pembelajaran kooperatif tipe TPS. Adapun rumus yang digunakan sebagai berikut :

1. Untuk menghitung rerata hasil belajar siswa

$$
\overline{\mathrm{X}}=\frac{\sum \mathrm{x}_{\mathrm{i}}}{\mathrm{n}}
$$

Keterangan :

$\sum \mathrm{xi}=$ Jumlah skor perolehan siswa

$\mathrm{n}=$ Jumlah siswa

$\bar{X}=$ Nilai rata-rata

2. Menghitung tingkat pencapaian ketuntasan belajar :

(Sudjana, 2002:94)

Secara individual \% TB $=\frac{\text { Nilai yang di capai }}{\text { Nilai Ideal }} \times 100 \%$

3. Menentukan persentase ketuntasan secara klasikal:

$\% \mathrm{~TB}=\frac{\Sigma \mathrm{TB}}{\mathrm{n}} \times 100 \%$

Keterangan :

$\sum \mathrm{TB} \quad=$ Jumlah siswa tuntas belajar

$\mathrm{n} \quad \quad=$ Jumlah siswa secara keseluruhan (Usman, 2001:139)

Indikator keberhasilan tindakan pembelajaran dalam penelitian ini yang mencakup dua aspek yaitu proses dan hasil. Dari segi proses skenario pembelajaran dikatakan terlaksana dengan baik apabila minimal $80 \%$ skenario pembelajaran dengan menggunakan model pembelajaran kooperatif Tipe TPS telah terlaksana dengan baik.

Sedangkan dari segi peningkatan hasil belajar IPS siswa dikatakan meningkat apabila minimal $70 \%$ dari keseluruhan siswa memperoleh skor $\geq 65$ yakni sesuai dengan kriteria ketuntasan minimal (KKM) yang ditetapkan oleh sekolah tempat melaksanakan penelitian.

\section{Hasil}

1. Aktifitas Guru

Aktivitas guru dalam menerapkan model pembelajaran pada pertemuan pertama mencapai skor 49 atau $72,1 \%$ sedangkan pada pertemuan kedua mencapai skor 58 atau 85,3\%. Hal ini menunjukkan bahwa aktivitas guru dalam KBM dari pertemuan pertama mengalami peningkatan pada pertemuan kedua. aktivitas guru dalam menerapkan model pembelajaran pada pertemuan pertama mencapai skor 66 atau 97,1\% sedangkan pada pertemuan kedua mencapai skor 68 atau 100\%. Hal ini menunjukkan bahwa aktivitas guru dalam KBM dari pertemuan pertama mengalami peningkatan pada pertemuan kedua dan berada dalam kategori baik.

2. Aktifitas Siswa

Presentase hasil observasi aktivitas siswa pada pertemuan pertama adalah 60,3\% mengalami peningkatan menjadi $72,1 \%$ pada pertemuan kedua. Sedangkan presentase hasil observasi aktivitas siswa pada pertemuan pertama adalah 91,2\% mengalami peningkatan menjadi 98,5\% pada pertemuan kedua. Hal ini menunjukkan bahwa hasil observasi aktivitas siswa dalam kategori baik.

3. Hasil Belajar Siswa

Pelaksanaan pembelajaran yang diikuti oleh siswa belum mencapai indikator dalam penelitian ini, yaitu sebesar $60,3 \%$ pada pertemuan pertama dan $72,1 \%$ pada pertemuan kedua. Sedangkan pelaksanaan pembelajaran yang dilakukan oleh guru telah mencapai $72,1 \%$ pada pertemuan pertama dan mengalami peningkatan pada pertemuan kedua sebesar $85,3 \%$ 
yang menunjukkan bahwa aktivitas guru dapat dikategorikan cukup. Demikian juga halnya dengan pelaksanaan pembelajaran yang diikuti oleh siswa sudah mencapai indikator dalam penelitian ini berdasarkan hasil observasi aktivitas siswa yaitu sebesar 91,2\% pada pertemuan pertama dan $98,5 \%$ pada pertemuan kedua. Sedangkan pelaksanaan pembelajaran yang dilakukan oleh guru telah mencapai $97,1 \%$ pada pertemuan pertama dan mengalami peningkatan pada pertemuan kedua sebesar $100 \%$ yang menunjukkan bahwa aktivitas guru dapat dikategorikan baik.

\section{Pembahasan}

Pada penelitian ini, siswa dibagi dalam 10 kelompok. Setiap kelompok terdiri dari dua orang. Pembentukan kelompok dilakukan dengan mempertimbangkan perbedaan kemampuan serta jenis kelamin. Hal ini sejalan dengan salah satu ciri model pembelajaran kooperatif yang dikemukakan oleh Arends (dalam Trianto 2010:65) menyatakan bahwa kelompok dibentuk dari siswa yang mempunyai kemampuan tinggi, sedang, dan rendah serta bila memungkinkan anggota kelompok berasal dari ras, budaya, suku dan jenis kelamin yang beragam. Analisis hasil observasi kegiatan siswa dalam pembelajaran menunjukkan bahwa pembelajaran dengan penerapan model pembelajaran kooperatif tipe Think-Pair-Share (TPS) memiliki dampak positif dalam meningkatkan hasil belajar siswa. Hal ini dapat dilihat dari hasil observasi kegiatan belajar siswa dari setiap pertemuan ke pertemuan selanjutnya.

Berdasarkan hasil observasi pada siklus I, kegiatan belajar siswa belum terlaksana dengan baik dan masih terdapat kekurangan-kekurangan yang harus diperbaiki. Hal ini terlihat dari hasil observasi yang dilakukan yang menunjukkan mash ada hal-hal belum sepenuhnya terlaksana secara maksimal diantaranya: (1) tidak semua siswa memberikan jawaban terhadap apersepsi dan motivasi yang dilakukan guru, (2) tidak semua siswa mendengarkan penjelasan guru tentang tujuan pembelajaran, (3) tidak semua siswa memperhatikan penjelasan materi dari guru, (4) tidak semua siswa mengerjakan LKS secara madiri, (5) tidak semua siswa dapat berkomunikasi secara baik dengan pasangannya, (6) masih ada beberapa siswa yang takut maju ke depan kelas untuk menuliskan hasil jawabannya, (7) belum semua siswa memperhatikan penjelasan guru tentang jawaban yang masih salah, (8) siswa masih banyak yang belum berani mengemukakan kesulitannya, (9) siswa kurang dilibatkan dalam membuat kesimpulan pelajaran.

Berdasarkan kekurangan-kekurangan tersebut, maka penelitian dilanjutkan pada siklus II. Pada siklus II siswa sudah dapat mengikuti pembelajaran dengan lebih baik, hal tersebut dapat dilihat dari meningkatnya hasil observasi siswa yaitu dari $91,2 \%$ pada pertemuan ketiga menjadi $98,5 \%$ pada pertemuan keempat. Untuk lebih jelasnya, persentase hasil observasi kegiatan belajar siswa dapat dilihat pada gambar berikut:

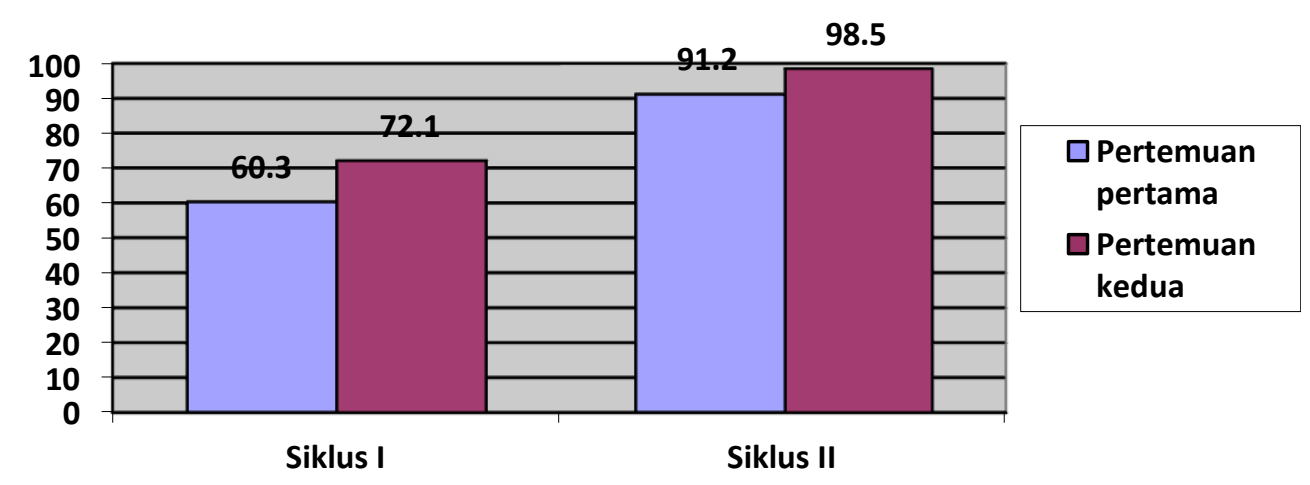




\section{Gambar 1. Grafik Persentase hasil kegiatan belajar siswa pada setiap siklus I dan II}

Analisis hasil observasi kegiatan siswa dalam pembelajaran menunjukkan bahwa pembelajaran dengan penerapan model pembelajaran kooperatif tipe Think-Pair-Share (TPS) memiliki dampak positif dalam meningkatkan kualitas kegiatan guru. Hal ini terlihat dari hasil observasi kegiatan guru pada setiap pertemuan. Pada siklus I, persentase kegiatan mengajar guru yaitu $72,1 \%$ pada pertemuan pertama dan meningkat menjadi $85,3 \%$ pada pertemuan kedua. Namun disadari masih terdapat kekurangan-kekurangn yang masih perlu diperbaiki, diantaranya: (1) guru menyampaikan materi pelajaran kurang sistematis dan agak cepat, (2) guru tidak membimbing semua siswa yang mengalami kesulitan, (3) guru tidak meminta siswa menanyakan materi pelajaran yang belum dimengerti, (4) guru tidak melibatkan siswa dalam membuat kesimpulan materi pelajaran.

Berdasarkan kekurangan yang ada pada siklus I maka pada siklus II peneliti lebih menitikberatkan perbaikan kekurangan tersebut agar pembelajaran berjalan lancar dan efektif. Untuk lebih jelasnya persentase hasil observasi kegiatan guru dapat dilihat dalam gambar berikut ini :

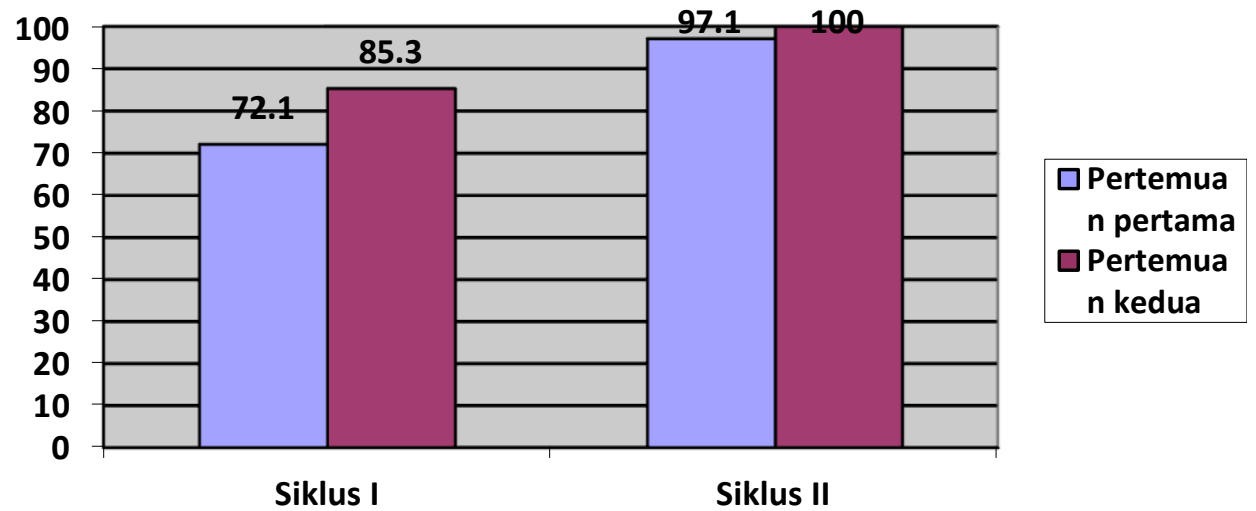

\section{Gambar 2. Grafik Persentase hasil observasi aktivitas guru siklus I dan II}

Untuk memperoleh hasil belajar, dilakukan evaluasi atau penilaian yang merupakan tindak lanjut atau cara mengukur tingkat penguasaan siswa. Dimana evaluasi atau tes yang diberikan setelah pembelajaran usai. Hal ini sejalan dengan pendapat Abdurrahman (dalam Jihad, 2010:14) menyatakan "hasil belajar adalah kemampuan yang diperoleh anak setelah melalui kegiatan belajar". Sedangkan menurut Juliah (dalam Jihad, 2010:15) menyatakan "hasil belajar adalah segala sesuatu yang menjadi milik siswa sebagai akibat dari kegiatan belajar yang dilakukannya".

Berdasarkan hasil penelitian yang telah dilakukan menunjukkan bahwa dengan menerapkan model pembelajaran kooperatif tipe Think-Pair-Share (TPS) dalam pembelajaran memiliki dampak positif dalam meningkatkan hasil belajar IPS siswa pada materi Kenampakan Alam dan Sosial Negara-negara Tetangga di Kelas VI SD Negeri 1 Duruka. Hal ini dapat dilihat dari adanya peningkatan hasil belajar siswa pada setiap siklus. Rata-rata hasil tes siklus I adalah 63,25 dengan presentase ketuntasan 35\%. Namun nilai tersebut belum mencapai standar indikator yang telah ditentukan. Kemudian pada siklus II, rata-rata hasil tes siklus II adalah 75,75 dengan presentase ketuntasan $85 \%$. Hal tersebut menunjukkan bahwa hasil belajar siswa telah mencapai indikator yang telah ditetapkan yaitu $70 \%$ siswa telah memperoleh nilai $\geq 65$. Lebih jelasnya, perbandingan ketuntasan belajar siswa pada siklus I dan siklus II dapat dilihat pada table berikut ini: 


\begin{tabular}{cclcc}
\hline No & Siklus & Hasil Belajar & $\begin{array}{c}\text { Jumlah } \\
\text { Siswa }\end{array}$ & $\begin{array}{c}\text { Persentase } \\
(\%)\end{array}$ \\
\hline \multirow{2}{*}{1} & \multirow{2}{*}{ I } & Tuntas & 7 & 35 \\
\cline { 3 - 5 } & & Tidak Tuntas & 13 & 65 \\
\hline \multirow{2}{*}{2} & \multirow{2}{*}{$\mathrm{II}$} & Tuntas & 17 & 85 \\
\cline { 3 - 5 } & & Tidak Tuntas & 3 & 15 \\
\hline
\end{tabular}

Tabel 1. Ketuntasan hasil belajar siswa secara klasikal setiap siklus

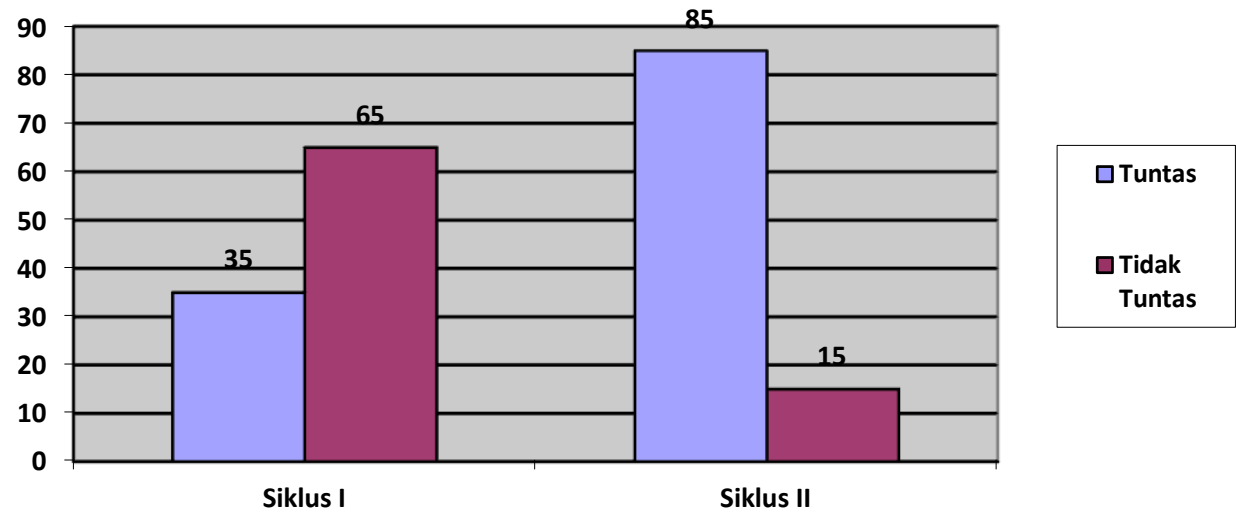

\section{Gambar 3. Grafik Presentase ketuntasan hasil belajar setiap siklus}

\section{Simpulan}

Berdasarkan hasil observasi, evaluasi dan pembahasan yang telah dilakukan dapat disimpulkan sebagai berikut: 1) Penerapan model pembelajaran kooperatif tipe Think-PairShare (TPS) dapat meningkatkan hasil belajar IPS materi Kenampakan Alam dan Sosial Negara-negara Tetangga pada siswa Kelas VI SD Negeri 1 Duruka. Hasil tes siklus 1 menunjukkan bahwa 7 dari 20 siswa Kelas VI telah mencapai nilai $\geq 65$ dengan persentase ketuntasan $65 \%$ dan rata-rata kelas 63,25. Pada siklus II persentase ketuntasan $85 \%$ dengan rata-rata kelas 75,75. Hasil belajar siswa tersebut menunjukkan bahwa indikator kinerja telah tercapai yaitu minimal $70 \%$ siswa memperoleh nilai $\geq 65$; 2) Berdasarkan hasil observasi pada siklus I dan siklus II persentase aktivitas siswa dalam mengikuti pembelajaran kooperatif tipe Think-Pair-Share (TPS) selalu meningkat, ini dapat dilihat dari pencapaian indikator. Pada siklus I aktivitas siswa mencapai $60,3 \%$ pertemuan pertama dan $72,1 \%$ pada pertemuan kedua. Pada siklus II meningkat menjadi $91,2 \%$ dan $98,5 \%$ pada pertemuuan terakhir. Hal tersebut menunjukkan bahwa siswa telah dapat mengikuti pembelajaran dengan menggunakan model pembelajaran kooperatif tipe Think-Pair-Share (TPS) dengan baik; 3) Dari hasil observasi pada siklus I dan siklus II persentase aktivitas guru dalam pembelajaran kooperatif tipe Think-Pair-Share (TPS) selalu meningkat, ini dapat dilihat dari pencapaian indikator. Pada siklus I aktivitas guru mencapai $72,1 \%$ pertemuan pertama dan $85,3 \%$ pada pertemuan kedua. Pada siklus II meningkat menjadi $97.1 \%$ dan $100 \%$ pada pertemuuan terakhir. Hal tersebut menunjukkan bahwa kegiatan 53 ajar guru dengan menggunakan model pembelajaran kooperatif tipe Think-Pair-Siıu , TPS) telah dilaksanakan dengan baik dan mencapai indikator kinerja.

\section{Referensi}


Fathurrohman P. dan Sutikno S., 2007. Strategi Belajar Mengajar. PT Refika Aditama. Bandung.

Hamalik O., 2003. Perencanaan Pengajaran. Rineka Cipta. Jakarta.

Hartini, dkk. (2016) Penerapan Model Pembelajaran Think-Pair-Share Untuk Mneingkatkan

Kemampuan Komunikasi Matematis Siswa SMP. KREANO Jurnal Matematika $\begin{array}{lllll}\text { Kreatif } & \text {-Inovatif } & \text { Vol. } & 7 & \text { Nomor }\end{array}$ https://journal.unnes.ac.id/nju/index.php/kreano/article/download/5009/6223.

Ibrahim R. Dan Syaodih S.N., 2003. Perencanaan Pengajaran. Rineke Cipta. Jakarta..

Jihad A. dan Haris A., 2010. Evaluasi Pembelajaran. Multi Pressindo. Yogyakarta.

Komalasari K., 2010. Pembelajaran Kontekstual. PT. Refika Aditama. Bandung.

Slameto, 2003. Belajar dan Faktor-faktor yang Mempengaruhinya. PT. Rineke Cipta. Jakarta.

Sudjana N., 2002. Penilaian Hasil Proses Belajar Mengajar. PT. Remaja Rosdakarya. Bandung.

Sugiyanto, 2010. Model-model Pembelajaran Inovatif. Yuma Pustaka. Surakarta.

Trianto, 2010. Mendesain Model Pembelajaran Inovatif-Progresif. Kharisma Putra Utama. Surabaya.

Usman U. M., 2001. Menjadi Guru Profesional. PT. Remaja Rosdakarya. Bandung. 